\title{
Children and Pesticides ${ }^{1}$
}

\author{
F.M. Fishel ${ }^{2}$
}

\section{Introduction}

Children act fast, but so do poisons, including pesticides.

Fortunately for most parents, their children are not harmed when the parents have a momentary lapse and aren't supervising them for a short time. But how would parents respond if they suddenly turn around, and their toddler is holding a can of household aerosol insect killer? This publication outlines some facts and precautionary measures regarding children and pesticides in the home environment, so parents have a better idea of how to keep harmful chemical products away from their children.

\section{Household Chemical Products}

A variety of household chemical products can be found in the home, and some of these contain pesticides. Many have the potential to cause harm, particularly to children. Examples include the following:

- bath and kitchen disinfectants and sanitizers, including bleach

- household cleaning or maintenance products, such as drain cleaner, paints, or glues

- automotive products, such as antifreeze or windshield washer fluid

- health or beauty care products such as medicines, hair and nail products

- ant and roach sprays and baits

- insect repellents
- rat and other rodent poisons

- lawn and garden pesticides

- products used to kill mold or mildew

- flea and tick shampoos, powders, and dips for pets

- swimming pool chemicals

All of the chemicals listed can potentially cause great harm, but many parents aren't aware that common household products used in and around the home contain pesticides. The very products used to kill ants, germs, cockroaches, flies, mice, rats, and termites to protect family health from vermin, pathogens, and the like can actually harm a child's health if stored or used improperly, allowing exposure to potentially highly toxic substances.

\section{Frequency of Poisoning Occurrence}

According to the U.S. Poison Control Centers, a call about someone having been exposed to a poison occurs every 13 seconds. Nearly $40 \%$ of those cases involve a child younger than three years of age. The American Association of Poison Centers (AAPC) 2011 annual report indicates that children younger than 3 years were involved in $36.2 \%$ of exposures, and children younger than 6 years accounted for nearly half (48.9\%) of all human exposures. Of the 1,158 reported human poisoning fatalities, the majority of the fatalities in children younger than or equal to 5 years of age were unintentional; however, only 20 fatalities

1. This document is $\mathrm{PI226}$, one of a series of the Agronomy Department, Florida Cooperative Extension Service, Institute of Food and Agricultural Sciences, University of Florida. Original publication date March 2010. Revised March 2013. Visit the EDIS website at http://edis.ifas.ufl.edu.

2. F.M. Fishel, professor, Department of Agronomy, and director, Pesticide Information Office, Institute of Food and Agricultural Sciences, University of Florida, Gainesville, FL 32611.

Use pesticides safely. Read and follow directions on the manufacturer's label. All chemicals should be used in accordance with directions on the manufacturer's label. 
(1.7\%) occurred in this age group. These are only the reported incidents; undoubtedly countless occurrences go unreported. Also in its 2011 annual report, AAPC stated that of the nearly 2.1 million calls received reporting exposure, more than $90 \%$ of the incidents had occurred in a residence. Table 1 summarizes the 10 most frequently reported substances involved in exposures to children age 5 and under.

Table 1. Substance categories most frequently involved in pediatric exposures*

\begin{tabular}{|l|l|l|}
\hline Substance category & Number & Percent \\
\hline Cosmetic/personal care products & 166,246 & 14.0 \\
\hline Analgesics & 117,378 & 9.8 \\
\hline Household cleaning products & 109,442 & 9.2 \\
\hline Foreign bodies/toys/miscellaneous & 82,197 & 6.9 \\
\hline Topical preparations & 78,114 & 6.6 \\
\hline Vitamins & 51,012 & 4.3 \\
\hline Antihistamines & 44,458 & 3.7 \\
\hline Pesticides & 39,124 & 3.3 \\
\hline Cold and cough preparations & 34,968 & 2.9 \\
\hline Antimicrobials & 33,582 & 2.8 \\
\hline *Includes all children with actual or estimated age of $\leq 5$ years \\
old.
\end{tabular}

\section{Children's Susceptibility}

The data show the need for everyone to securely store any substance, including pesticides and household cleaning products, out of children's reach. Children are curious by nature, but they also spend time outdoors where pesticides may be present on lawns and play equipment. They crawl on carpeted floors that may have been treated with pesticides. They play with pets that may have been treated, and they engage in frequent hand-to-mouth contact (Figure 1).

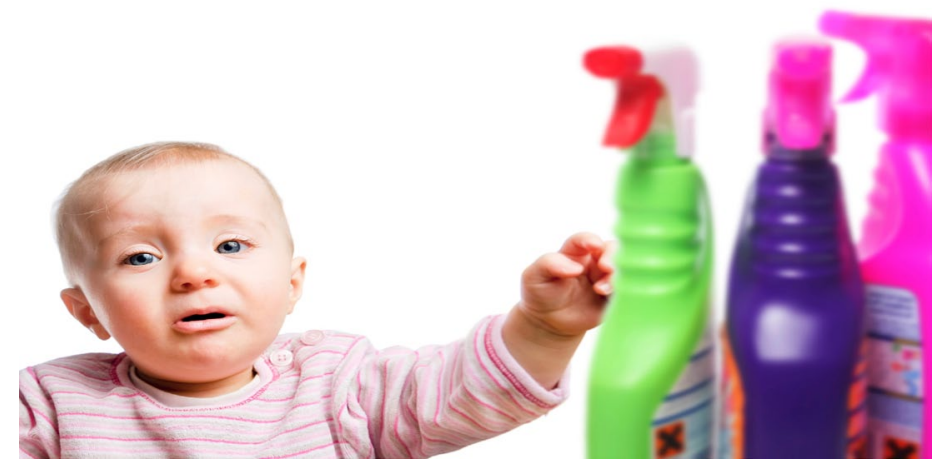

Figure 1. Children are curious by nature, so it is necessary to keep household cleaners, pesticides, and anything with harmful chemicals out of their reach.

Credits: http://www.thinkstock.com
Compared to adults, children's nervous, immune, digestive, and other bodily systems are still developing, making them less able to metabolize, detoxify, and excrete pollutants.

\section{Preventing the Accident}

Preventing children from pesticide exposure in the home environment does not require an elaborate plan. Some simple, commonsense recommendations include the following:

- Pest exclusion can prevent or minimize the need for pesticide use within the home.

- Always read the pesticide product's label first. All labels are required to bear the statement "KEEP OUT OF REACH OF CHILDREN," but strict attention should be given to all the label directions.

- Never leave products, application equipment, or contaminated protective gear unattended.

- Use child-resistant packaging properly and re-close if interrupted during use.

- Never transfer or store pesticides in other containers, such as those used for food and drink (Figure 2).

- Always store pesticides (and other potentially harmful household products) in a locked cabinet, closet, locker, or garden shed.

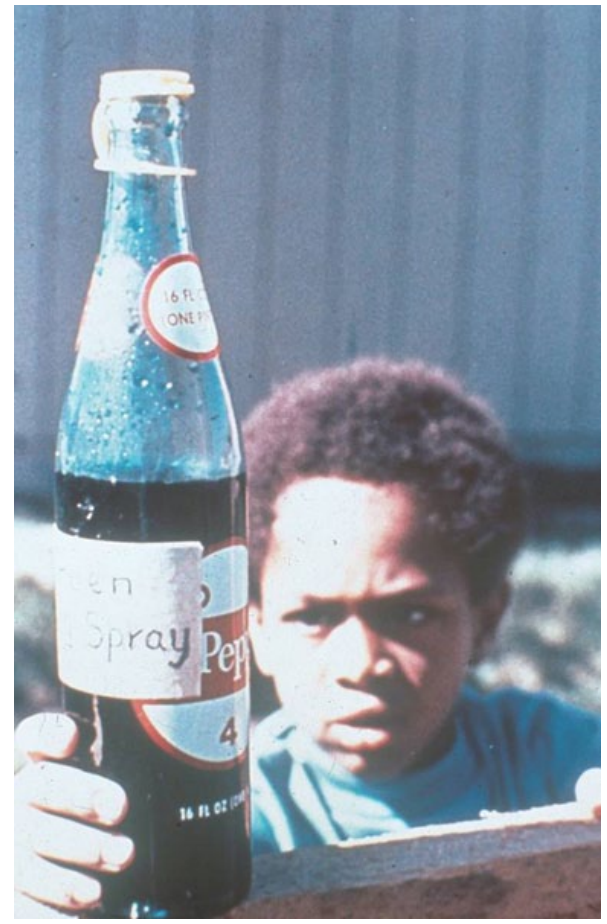

Figure 2. Never store pesticides in containers intended for food and drink.

Credits: UF/IFAS Pesticide Information Office 
- Remove children, pets, and their toys before applying pesticides to any area. Most product labels state to keep out of treated areas until sprays have dried. Some labels may contain additional directions for washing food-processing surfaces and utensils prior to reuse if applicable.

- Rodenticide products (pesticides used for control of mice and rats) will state directions concerning placement and use with tamper-resistant bait stations.

- Post the Poison Control Center telephone number (1-800-222-1222) near every phone.

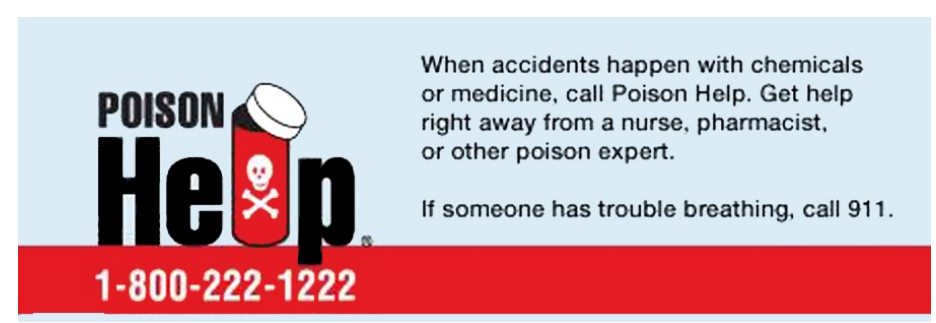

Figure 3. When accidents happen with chemicals or medicine, call Poison Help at 1-800-222-1222. If someone has trouble breathing, call 911.

Credits: U.S. Department of Health Resources and Services

Administration, http://poisonhelp.hrsa.gov/

\section{Additional Information}

American Association of Poison Control Centers. http:// www.aapcc.org/.

Fishel, F.M. 2013. Protecting Your Pet from Pesticides. PI-81. Gainesville: University of Florida Institute of Food and Agricultural Sciences. http://edis.ifas.ufl.edu/pi118.

Florida Poison Information Center Network. 1-800-2221222 or http://www.fpicn.org.

National Pesticide Information Center. 1-800-858-7378 or http://npic.orst.edu/.

Nesheim, O.N., F.M. Fishel, and M.A. Mossler. 2011. Toxicity of Pesticides. PI-13. Gainesville: University of Florida Institute of Food and Agricultural Sciences. http://edis.ifas. ufl.edu/pi008. 